\title{
ELIA
}

Estudios de Lingüística Inglesa Aplicada

\section{KEY CONCEPTS IN APPLIED LINGUISTICS/CONCEPTOS CLAVE DE LA LINGÜÍSTICA APLICADA}

\section{The Use of Previously Known Languages by L2 Learners: A not so Clear-Cut Phenomenon}

\section{María Martínez-Adrián}

The University of the Basque Country (UPV/EHU), Spain

\section{maria.martineza@ehu.eus}

As is well known, second language (L2) learners resort to their previously known languages, among other issues, when confronted with communication problems during interaction or for task-related procedures, as illustrated in (1) (use of Spanish) and (2) (use of Catalan):

(1) CHI1: cómo se dice enfadada? [how do you say angry?] CHI2: cross? (From Martínez-Adrián \& Arratibel-Irazusta, 2020)

(2) CHA: et toca a tu, no? [it's your turn, isn't it?] (From Vraciu \& Pladevall-Ballester, 2020)

Even though the use of previously known languages by L2 learners during production is so evident, its conception is not so crystal-clear. First of all, its investigation has been approached from a cognitive (i.e. Poulisse, 1993) and a sociocultural perspective (i.e. Antón \& DiCamilla, 1998; Swain \& Lapkin, 2000). Second, this study 
gains in complexity when multilingual learners are the target of these investigations (Cenoz, 2001), as not only the mother tongue/s but any other language known by the learner could be employed during production.

This paper delves into the complexities of the use of previously known languages by L2 learners as regards its conceptualisation, issues related to the methodology employed for its investigation and the analysis of the variables that determine its use. To this end, I will first of all outline the main theoretical approaches to the study of this phenomenon, highlighting the main uses of previously known languages considered within them, the factors examined and the type of designs followed. It goes on to present several methodological issues which might explain the existence of mixed results in the literature. The last part of the paper is devoted to the interaction existing among the variables under investigation which brings to light its not so straightforward relationship.

From a cognitive perspective, it is customary to speak about crosslinguistic influence as a learning strategy and a communication strategy. As for crosslinguistic influence as a learning strategy, learners make use of prior linguistic experience to construct hypotheses in the L2 (Schachter, 1983), which are later on tested by searching confirmatory or disconfirmatory input. In the case of crosslinguistic influence as a communication strategy, learners employ their previously known languages (as well as other devices such as miming, avoidance, appeals for assistance) to compensate for the lack of knowledge during production (Dörnyei \& Scott, 1997). 
In general terms, the study of communication strategies has been approached from two different perspectives: interactional (i.e. Tarone \& Yule, 1987) and psycholinguistic (i.e. Poulisse, 1993). Existing taxonomies in both perspectives include previously known language-based strategies. While Tarone's (1983) taxonomy includes conscious transfer encompassing both language switch (Turkish 'balon' for 'ballon' (from Tarone, 1983)) and literal translation ('He invites him to drink' for 'They toast one another' (from Tarone, 1983)), Poulisse, Bongaerts, and Kellerman (1990) talk about transfer strategies which are broken down into borrowings (Dutch 'etalage' for English 'shop-window'), foreignizings ('cuffer' from French 'coiffeur') (Poulisse, 1990, p. 60)) and literal translations ('my elders' for English 'parents') (Poulisse, 1990, p. 109)).

The bulk of studies exploring the use of communication strategies by L2 learners have devoted their attention to the classification of communication strategies, effectiveness of communication strategies, factors affecting choice of communication strategies, and teachability of communication strategies. In particular, among the factors examined in these investigations, proficiency in the target language (i.e. ArratibelIrazusta \& Martínez-Adrián, 2018, 2019; Bialystok, 1983; Jourdain, 2000; Gallardo-del-Puerto, Basterrechea, \& Martínez-Adrián, 2020; Liskin-Gasparro, 1996; Muñoz, 2007; Paribakht, 1985; Poulisse, Bongaerts, \& Kellerman, 1990; Tarone, 1977), personality (Haastrup \& Philipson, 1983; Luján Ortega \& Clark-Carter, 2000); age (Cenoz, 2001; Gost \& Celaya, 2005), learning and cognitive style (Luján Ortega \& Clark-Carter, 2000; Littlemore, 2001); gender (Basterrechea, Martínez-Adrián, \& Gallardo-del-Puerto, 2017; 
Jiménez Catalán, 2003; Wang, 2008); task-type and task-related features such as cognitive demands, time constraints and interlocutor's role (Poulisse Bongaerts, \& Kellerman, 1990; Khanji, 1993; Viladot \& Celaya, 2007) and learning programme (CLIL vs. Non-CLIL learning context) (Agustín-Llach, 2009; Celaya, 2008; Celaya \& Ruiz de Zarobe, 2010; Gallardo-del-Puerto, 2015; MartínezAdrián \& Gutiérrez-Mangado, 2015; Pladevall Vallester \& Vraciu, 2017) have been found to affect the frequency and choice of communication strategies.

Some of these studies have examined production data (oral and written) (i.e. Agustín Llach, 2009; Arratibel-Irazusta \& MartínezAdrián, 2018, 2019; Caballero \& Celaya, 2019; Cenoz, 2001, 2003; Gost \& Celaya, 2005; Muñoz, 2007; Poulisse \& Bongaerts, 1994), while others have examined learners' self-reported use of communication strategies (i.e. Kaivanpanach et al., 2012; MartínezAdrián, Gallardo-del-Puerto, \& Basterrechea, 2019; Ollo Jiménez \& Martínez-Adrián, 2019; Purdie \& Oliver, 1999). The target of these investigations has been primarily adult and adolescent learners (i.e. Barea Neira, 2018; Fernández Dobao, 2001; Ghout-Khenoune, 2012; Martínez-Adrián \& Gutiérrez-Mangado, 2015, Poulisse, Bongaerts, \& Kellerman, 1990; Rosas Maldonado, 2016) but primary-school learners are receiving increasing attention in recent years (Agustín Llach, 2009, 2016; Gallardo-del-Puerto, 2015; Gallardo-del-Puerto, Basterrechea \& Martínez-Adrián, 2020; Pladevall-Ballester \& Vraciu, 2017)

From a sociocultural perspective, the use of previously known languages is considered an essential tool that assists learners during collaborative tasks and mediates their own mental activity through private speech (Alegría De La Colina \& García Mayo, 2009;

\section{ELIA 20, 2020, pp. 191-208 DOI: http://dx.doi.org/10.12795/elia.2020.i20.07}


Antón \& DiCamilla, 1998; Brooks \& Donato, 1994; Storch \& Wigglesworth, 2003; Swain \& Lapkin, 2000). L2 learners use their previously known languages for functions such as task management (i.e. to plan, organize and monitor the activity), grammar and vocabulary deliberations, off-task talk (i.e. casual talk) and phatics (i.e. the use of expressions such as $o k$, well, and so in the learners' previously known languages to facilitate the flow of speech). Factors such as proficiency level in the target language (DiCamilla \& Antón, 2012; Martínez-Adrián, 2020a; Storch \& Aldosari, 2010; Swain \& Lapkin, 2000; Vraciu \& Pladevall-Ballester, 2020), gender (Azkarai, 2015; Azkarai \& Imaz Agirre, 2017; Ross-Feldman, 2005), type of learning programme (CLIL vs. Non-CLIL) (García Mayo \& Hidalgo Gordo, 2017; García Mayo \& Lázaro Ibarrola, 2015; Martínez-Adrián, 2020b), task-type (Azkarai \& García Mayo, 2017; Alegría de la Colina \& García Mayo, 2009; Rayati, Yaqubi, \& Harsejsani, 2012; Storch \& Wigglesworth, 2003) and task-modality (Azkarai \& García Mayo, 2015; Martínez-Adrián \& Arratibel-Irazusta, 2020; Payant \& Kim, 2019) have been found to affect the use of previously known languages during task-based interaction. This line of research has been particularly evident in the case of adult learners, but in the last five years, researchers are especially committed to the study of young learners so as to offer this population the best learning conditions (García Mayo, 2018).

In addition to the existence of different theoretical approaches for this phenomenon, when it comes to the methodology employed in investigations framed within cognitive or sociocultural theories, its study is not without limitations and intricacies, which may explain the existence of mixed results in the literature. First of all, in a good number of studies it is typical to observe how several 
strategies or categories are merged under a higher-order category. For example, the use of borrowings, foreignizings and calques are typically included within the category 'transfer'. Even if this categorization is correct and in line with the taxonomy devised in the Nijmegen project ${ }^{1}$ (Poulisse, Bongaerts, \& Kellerman, 1990), more robust conclusions can be drawn if the three strategies within 'transfer' are treated individually as they have been found not to follow the same path in different studies (see Agustín Llach, 2016; Arratibel-Irazusta \& Martínez-Adrián, 2018; Gallardo-del-Puerto, 2015; Gallardo del Puerto, Basterrechea, \& Martínez-Adrián, 2020). Likewise, the existence of different categorizations and tags both in cognitive and sociocultural perspectives adds further complexity. For instance, while certain studies talk about 'conscious transfer', other investigations talk about 'borrowings' within the cognitive strand. Similarly, while some studies within the sociocultural strand consider the use of previously known languages for metacognitive purposes (i.e. task-related procedures), other investigations speak about the use of these languages for metacomments instead. Apart from the problematicity as regards the existence of different tags, it is also important to tackle not only amount/frequency of use of learners' previously known languages but also a more detailed analysis of the different functions and the most common manifestations of these languages, alongside the study of the use of the target language. This type of analysis will widen the scope of the study and will provide a fairer picture of the use of the learner's

\footnotetext{
${ }^{1}$ This project on the use of communication strategies by first language (L1) Dutch learners of L2 English was pioneer in devising a more comprehensive taxonomy and in providing a more exhaustive study of proficiency and task effects.
} 
language repertoire in the multilingual class. The use of a wide array of tasks is another issue that may lead to mixed results. Studies on the effect of proficiency on the use of previously known languages have attested different findings when examining foreignizings (Agustín Llach, 2009; Arratibel-Irazusta \& MartínezAdrián, 2018; Celaya, 2008; Gallardo-del-Puerto, 2015; MartínezAdrián, Gallardo-del-Puerto, \& Basterrechea, 2019). While in oral production and in self-report questionnaires, less proficient learners have been found to favor the use of this strategy, studies examining written production have proved the opposite. Mixed results may also be explained by the small gap in proficiency existing between the groups tested. The review of different investigations that have examined learners with small differences in terms of proficiency levels (Arratibel-Irazusta \& Martínez-Adrián, 2018, 2019; Gallardodel-Puerto, Basterrechea, \& Martínez-Adrián, 2020) suggests the inclusion of a wider gap between groups that could potentially yield larger differences, all of which could lead to a more thorough view of strategy development.

Apart from these methodological issues, we cannot dismiss the interaction existing among the variables under investigation, which has been attested in studies carried out within the cognitive and sociocultural strand. Studies on communication strategies that have looked into the variable 'proficiency in the target language' have revealed how proficiency is sometimes overruled by the nature of the task in adult learners. In this case, in highly-demanding tasks, advanced learners have been found to employ previously known language-based strategies (Fernández Dobao, 2002; Poulisse, Bongaerts, \& Kellerman, 1990). Similarly, several investigations examining child and adolescent learners immersed in a CLIL 
programme have concluded that proficiency may be overruled by participation in this type of educational programme, as beginner learners participating in these bilingual programmes have been observed to employ L2-based strategies more typical of advanced learners (i.e. the use of paraphrasing in the target language) (Arratibel-Irazusta \& Martínez-Adrián, 2019; Martínez-Adrián, 2020a; Martínez-Adrián, Gallardo-del-Puerto, \& Basterrechea, 2019). Likewise, proficiency has been found to interact with the variable 'age' in younger learners and adolescents, as older participants have been found to use their previously known languages to a higher extent, especially for less cooperative and more external-to-the task categories such as metacomments (i.e. metacognitive talk), discourse markers (i.e. phatics) and private speech (ArratibelIrazusta \& Martínez-Adrián, 2018; García Mayo \& Hidalgo Gordo, 2017; García Mayo \& Imaz Agirre, 2017; García Mayo \& Lázaro Ibarrola, 2015; Martínez-Adrián, 2020a).

These results are also in line with other studies conducted with young learners that have explored proficiency-pairings and time effects (Vraciu \& Pladevall Ballester, 2020), according to which older children make more use of their previously known languages at age 11-12, when learners display more analytic abilities in language learning and a higher level of metalinguistic awareness. In a similar vein, investigations within the sociocultural strand that have analysed the impact of the variable 'task-modality' in child learners (Martínez-Adrián \& Arratibel-Irazusta, 2020) indicate that it has a limited impact on the functions of previously known languages. Unlike adults, young learners employ them for discussing vocabulary issues in both speaking tasks as well as in speaking+writing tasks, while grammar talk among these learners

\section{ELIA 20, 2020, pp. 191-208 DOI: http://dx.doi.org/10.12795/elia.2020.i20.07} 198 
is uncommon in this population. These young learners are in the need of vocabulary to move the task forward and they rely on their previously known languages to avoid communication breakdowns. However, their still developing metalanguage skills might explain their lower reliance on their previously known languages for grammar discussions.

This clearly reinforces not only the need for research with young learners given their uniqueness in their engagement in the language learning process (Mackey \& Gass, 2005 as cited in Oliver \& Azkarai, 2017) but also the examination of age effects within this population. In this respect, other investigations with children which have focused on different issues from the use of previously known languages such as vocabulary acquisition have revealed that age and its associated cognitive processes may have an impact on the performance of communicative tasks in young learners. Iglesias Diéguez (2020) has shown how 6th year primary school learners seem to be more resourceful and to communicate more successfully than 4th year students when performing a storytelling task. Similarly, tasks with a written output appear to be more beneficial for 6th year learners than for their younger counterparts, as they focus on accuracy to a higher extent, showing a similar pattern to adult learners in this case (Niu, 2009; Payant \& Kim, 2019).

Thus, the mediating effect of variables such as the nature of the task (see Fernández Dobao, 2002; Poulisse, Bongaerts, \& Kellerman, 1990), the learning context (Arratibel-Irazusta \& Martínez-Adrián, 2019; Martínez-Adrián, 2020a; Martínez-Adrián, Gallardo-del-Puerto, \& Basterrechea, 2019) and age (ArratibelIrazusta \& Martínez-Adrián, 2018; García Mayo \& Hidalgo Gordo, 2017; García Mayo \& Imaz Agirre, 2017; García Mayo \& Lázaro 
Ibarrola, 2015; Martínez-Adrián, 2020a) should not be overlooked when conducting research on the effect of other variables (i.e. proficiency, task-modality, pairing method) on the use of previously known languages.

In conclusion, what I have shown in this article regarding the use of previously known languages during L2 production has clear implications both for research and for the multilingual class. Researchers should not dismiss the existence of different theoretical underpinnings explaining this phenomenon and the language repertoire in multilinguals which adds further complexity to the categorization of the data. In addition, methodological issues observed in the literature to the present date should be taken into account by researchers when designing their investigations as well as when discussing and interpreting their data: (i) the existence of different tags for the categorization of previously known language use, (ii) the combination of two or more strategies under a higherorder category, (iii) the analysis of both frequency and most common manifestations of both previously known language and target language use, (iv) the examination of a wide range of tasks, and (v) the comparison between groups with narrow gaps in age/proficiency. This will help researchers achieve greater validity and reliability in their investigations. Likewise, what has been reported here regarding the interaction among variables needs to be particularly stressed if we want to make the most of previously known languages in the multilingual class and maximize learning opportunities. 


\section{Acknowledgements}

The author would like to acknowledge the grants awarded by the Spanish Ministry of Economy and Competitiveness (FFI2016-74950-P) (AEI/FEDER/UE) and the Basque Government (IT904-16).

\section{References}

Agustín Llach, M.P. (2009). The role of Spanish L1 in the vocabulary use of content and non-content EFL learners. In Y. Ruiz de Zarobe, \& R.M. Jiménez Catalán (Eds.), Content and language integrated learning: Evidence from research in Europe (pp. 112-129). Bristol: Multilingual Matters. https://doi.org/10.21832/9781847691675-010

Agustín Llach, M. P. (2016). Age and type of instruction (CLIL vs. Traditional $\mathrm{EFL}$ ) in lexical development. International Journal of English Studies, 16(1), 75-96. https://doi.org/10.6018/ijes/2016/1/220691

Alegría de la Colina, A., \& García Mayo, M. P. (2009). Oral interaction in taskbased EFL learning: The use of the $\mathrm{L} 1$ as a cognitive tool. International Review of Applied Linguistics (IRAL), 473), 325-345. https://doi.org/10.1515/iral.2009.014

Antón, M. \& DiCamilla, F. (1998). Socio-cognitive functions of L1 collaborative interaction in the L2 classroom. The Modern Language Journal, 83(2), 233-247. https://doi.org/10.1111/0026-7902.00018

Arratibel-Irazusta, I., \& Martínez-Adrián, M. (2018). The use of previously known languages in the oral production of L3 English learners: A pseudolongitudinal study. European Journal of Applied Linguistics, 6(2), 229-254. https://doi.org/10.1515/eujal-2017-0001

Arratibel-Irazusta, I., \& Martínez-Adrián, M. (2019). The use of communication strategies in L3 English CLIL learners. In M. J. Gutiérrez-Mangado, M. Martínez-Adrián, \& F. Gallardo-del-Puerto (Eds.), Crosslinguistic influence: From empirical evidence to classroom practice (pp. 169189). Dordrecht: Springer. https://doi.org/10.1007/978-3-030-220662_9

Azkarai, A. (2015). L1 use in EFL task-based interaction: A matter of gender? European Journal of Applied Linguistics, 3(2), 159-179. https://doi.org/10.1515/eujal-2014-9911 
Azkarai, A., \& Imaz Agirre, A. (2017). Gender and age in child interaction in an EFL CLIL context: An exploratory study. In M. P. García Mayo (Ed.), Learning foreign languages in primary school: Research insights (pp. 103-123). Clevedon: Multilingual Matters. https://doi.org/10.21832/9781783098118-008

Azkarai, A., \& García Mayo, M. P. (2015). Task modality and L1 use in EFL oral interaction. Language Teaching Research, 19, 550-571. https://doi.org/10.1177/1362168814541717

Azkarai, A., \& García Mayo, M. P. (2017). Task repetition effects on L1 use in EFL child task-based interaction. Language Teaching Research, 21, 480-495. https://doi.org/10.1177/1362168816654169

Barea Neira, G. (2018). The use of previously known language-based strategies and self-regulatory strategies to compensate for the lack of fluency: $A$ pseudo-longitudinal study of L3 English university learners. Unpublished master's thesis, University of the Basque Country, Spain. Basterrechea, M., Martínez-Adrián, M., \& Gallardo-del-Puerto, F. (2017). Gender effects on strategic competence: a survey study on compensatory strategies in a CLIL context. ELIA, 17(17), 47-70. https://doi.org/10.12795/elia.2017.i17.03

Bialystok, E. (1983). Some factors in the selection and implementation of communication strategies. In C. Færch, \& G. Kasper (Eds.), Strategies in interlanguage communication (pp. 100-118). London: Longman.

Brooks, F., \& Donato, R. (1994). Vygotskyan approaches to understanding foreign language learner discourse during communicative tasks. Hispania, 77, 262-274. https://doi.org/10.2307/344508

Caballero, N. \& Celaya, M. L. (2019). Code-switching by primary school bilingual EFL learners: A study on the effect of proficiency and modality of interaction. International Journal of Bilingual Education and Bilingualism. https://doi.org/10.1080/13670050.2019.1671309

Celaya, M.L. (2008). 'I study natus in English': Lexical transfer in CLIL and regular learners. In R. Manroy, \& A. Sánchez (Eds.), 25 Años de lingüística aplicada en España: Hitos y retos (pp. 43-49). Murcia: Editum (Ediciones de la Universidad de Murcia).

Celaya, M.L., \& Ruiz de Zarobe, Y. (2010). First language and age in CLIL and non-CLIL contexts. International CLIL Research Journal, 1, 60-66. 
Cenoz, J. (2001). The effect of linguistic distance, L2 status and age on crosslinguistic Influence in third language acquisition. In J. Cenoz, B. Hufeisen, \& U. Jessner (Eds.), Cross-linguistic influence in third language acquisition: Psycholinguistic perspectives (pp. 8-20). Clevedon: Multilingual Matters. https://doi.org/10.21832/9781853595509

Cenoz, J. (2003). Cross-linguistic influence in third language acquisition: Implications for the organization of the multilingual mental lexicon. Bulletin VALS-ASLA (Vereinigung fur angewandte Linguistik in der Schweiz), 78, 1-11.

DiCamilla, F., \& Antón, M. (2012). Functions of L1 in the collaborative interaction of beginning and advanced second language learners. International Journal of Applied Linguistics, 22, 160-188. https://doi.org/10.1111/j.1473-4192.2011.00302.x

Dörnyei, Z., \& Scott, M.L. (1997). Communication strategies in a second language: definitions and taxonomies. Language Learning, 47, 173210. https://doi.org/10.1111/0023-8333.51997005

Fernández Dobao, A. (2001). Communication Strategies in the interlanguage of Galician students of English: the influence of learner- and taskrelated factors. Atlantis, 23(1), 41-62.

Fernández Dobao, A. M. (2002). The effect of language proficiency on communication strategy use: A case study of Galician learners of English. Miscelánea: A journal of English and American studies, 25, 53-75.

Gallardo-del-Puerto, F. (2015). L1 influence in CLIL vs. EFL schoolchildren: A study of codeswitching and transfer lapses. Unpublished paper presented at the 33th AESLA International Conference, Universidad Politécnica de Madrid, Spain, 16-18 April.

Gallardo-del-Puerto, F., Basterrechea, M., \& Martínez-Adrián, M. (2020). Target language proficiency and reported use of compensatory strategies by young CLIL learners. International Journal of Applied Linguistics, 30(1), 3-18. https://doi.org/10.1111/ijal.12252

García Mayo, M. P. (2018). Child task-based interaction in EFL settings: Research and challenges. International Journal of English Studies, 18(2), 119-143. https://doi.org/10.6018/ijes/2018/2/319731 
García Mayo, M. P., \& Hidalgo Gordo, M. A. (2017). L1 use among young EFL mainstream and CLIL learners in task-supported interaction. System, 67, 132-145. https://doi.org/10.1016/j.system.2017.05.004

García Mayo, M.P., \& Imaz Agirre, A. (2017). Child EFL interaction; age, instructional setting and development. In J. Enever, \& E. Lindgren (Eds.), Researching the complexity of early language learning in instructed contexts (pp. 249-268). Bristol, United Kingdom: Multilingual Matters. https://doi.org/10.21832/9781783098323-016

García Mayo, M. P., \& Lázaro Ibarrola, A. (2015). Do children negotiate for meaning in task-based interaction? Evidence from CLIL and EFL settings. System, 54, 40-54. https://doi.org/10.1016/j.system.2014.12.001

Gost, C., \& Celaya, M. L. (2005). Age and the use of the L1 in EFL oral production. In M.L. Carrió Pastor (Ed.), Perspectivas interdisciplinares de la linguística aplicada (pp. 129-136). Valencia: Universitat Politècnica de València.

Ghout-Khenoune, L. (2012). The effects of task type on learners' use of Communication Strategies. Procedia. Social and behavioral sciences, 69, 770-779. https://doi.org/10.1016/j.sbspro.2012.11.472

Haastrup, K., \& Phillipson, R. (1983). Achievement strategies in learner/native speaker interaction. In C. Færch, \& G. Kasper (Eds.), Strategies in interlanguage communication (pp. 140-158). London: Longman.

Iglesias Diéguez, K. (2020). Are vocabulary tasks effective for vocabulary acquisition? Evidence from collaborative dialogue in young EFL learners. Unpublished MA Dissertation. The University of the Basque Country.

Jiménez Catalán, R.M. (2003). Sex differences in L2 vocabulary learning Strategies. International Journal of Applied Linguistics, 13, 54-77. https://doi.org/10.1111/1473-4192.00037

Jourdain, S. (2000). A native-like ability to circumlocute. The Modern Language Journal, 84, 185-195. https://doi.org/10.1111/0026-7902.00061

Kaivanpanah, S., Yamouty, P., \& Karami, H. (2012). Examining the effects of proficiency, gender, and task type on the use of communication strategies. Porta Linguarum, 17, 79-93.

Khanji, R. (1993). Interlanguage talk: The relation between task types and CS among EFL Arab learners. In J.E. Alatis (Ed.), Georgetown University 
round table on language and linguistics 1993 (pp. 428-436). Washington D.C.: Georgetown University Press.

Liskin-Gasparro, J.E. (1996). Circumlocution, communication strategies, and the ACTFL proficiency guidelines: An analysis of student discourse. Foreign Language Annals, 29, 317-330.

Luján-Ortega, V., \& Clark-Carter, D (2000). Individual differences, strategic performance and achievement in second language learners of Spanish. Studia Linguistica, 54, 280-287. https://doi.org/10.1111/1467$\underline{9582.00067}$

Littlemore, J. (2001). An empirical study of the relationship between cognitive style and the use of communication strategy. Applied Linguistics, 22, 241-265. https://doi.org/10.1093/applin/22.2.241

Martínez-Adrián, M. (2020a). The use of previously known languages and target language (English) during task-based interaction: A pseudolongitudinal study of primary-school CLIL learners. EuroAmerican Journal of Applied Linguistics and Languages, 71), 59-77. https://doi.org/10.21283/2376905X.11.191

Martínez-Adrián, M. (2020b). ¿Los juntamos? A study of L1 use in interactional strategies in CLIL vs. non-CLIL primary school learners. International Review of Applied Linguistics in Language Teaching (IRAL), 58(1), 127. https://doi.org/10.1515/iral-2015-0120

Martínez-Adrián, M., \& Arratibel-Irazusta, I. (2020). The interface between taskmodality and the use of previously known languages in young CLIL English learners. Studies in Second Language Learning and Teaching, 10(3), 473-500. https://doi.org/10.14746/ssllt.2020.10.3.4

Martínez-Adrián, M., \& Gutiérrez-Mangado, M.J. (2015). L1 use, lexical richness, accuracy and complexity in CLIL and non-CLIL learners. Atlantis, Journal of the Spanish Association for Anglo-American Studies, 37, 175-197.

Martínez-Adrián, M., Gallardo-del-Puerto, F., \& Basterrechea, M. (2019). On selfreported use of communication strategies by CLIL learners in primary education. Language Teaching Research, 23(1), 39-57.

Muñoz, C. (2007). Cross-linguistic influence and language switches in L4 oral production. Vigo International Journal of Applied Linguistics, 4, 7394. 
Niu, R. (2009). Effect of task-inherent production modes on EFL learners' focus on form. Language Awareness, 18(3-4), 384-402. https://doi.org/10.1080/09658410903197256

Oliver, R., \& Azkarai, A. (2017). Review of child second language acquisition (SLA): Examining theories and research. Annual Review of Applied Linguistics, 37, 62-76. https://doi.org/10.1017/S0267190517000058

Ollo Jiménez, P., \& Martínez-Adrián, M. (2019). A study of self-reported opinions of L1-based communication strategies in CLIL and NONCLIL secondary-school learners of L3 English. RAEL: Revista Electrónica de Linguística Aplicada, 18(1), 72-90. https://doi.org/10.1515/iral-2015-0120

Paribakht, T. (1985). Strategic competence and language proficiency. Applied Linguistics, 6, 132-146. https://doi.org/10.1093/applin/6.2.132

Payant, C., \& Kim, Y. J. (2019). Impact of task modality on collaborative dialogue among plurilingual learners: A classroom-based study. International Journal of Bilingual Education and Bilingualism, 22(5), 614-627. https://doi.org/10.1080/13670050.2017.1292999

Pladevall-Ballester, E., \& Vraciu, A. (2017). Exploring early EFL: L1 use in oral narratives by CLIL and non-CLIL primary school learners. In M.P. García Mayo (Ed.), Learning foreign languages in primary school: Research insights (pp. 124-148). Clevedon: Multilingual Matters. https://doi.org/10.21832/9781783098118-009

Poulisse, N. (1990). The use of compensatory strategies by Dutch learners of English. Dordrecht: Foris.

Poulisse, N. (1993). A theoretical account of lexical communication strategies. In R. Schreuder, \& B. Weltens (Eds.), The bilingual lexicon (pp. 157-189). Amsterdam:John Benjamins. https://doi.org/10.1075/sibil.6.09pou

Poulisse, N., \& Bongaerts, T. (1994). First language use in second language production. Applied Linguistics, 15, 36-57. https://doi.org/10.1093/applin/15.1.36

Poulisse, N., Bongaerts, T., \& Kellerman, E. (1990). The use of Compensatory Strategies by Dutch learners of English. Dordrecht: Foris.

Purdie, N., \& Oliver, R. (1999). Language learning strategies used by bilingual school-aged children. System, 27, 375-380. https://doi.org/10.1016/S0346-251X(99)00032-9 
Rayati, R. A., Yaqubi, B., \& Harsejsani, R. (2012). L1 use and language-related episodes (LREs) in an EFL setting. The Journal of Teaching Language Skills (JTLS), 3(4), 99-125.

Rosas Maldonado, M. (2016). Communication strategies used by different level L2 English learners in oral interaction. Revista Signos, 4990), 71-93. https://doi.org/10.4067/S0718-09342016000100004

Ross-Feldman, L. (2005). Task-based interactions between second language learners: Exploring the role of gender. Unpublished doctoral dissertation. Georgetown University.

Schachter, J. (1983). A new account of language transfer. In S. Gass, \& L. Selinker (Eds.), Language transfer in language learning (pp. 98-111). Rowley, MA: Newbury House.

Storch, N., \& Aldosari, A. (2010). Learners' use of first language (Arabic) in pair work in an EFL class. Language Teaching Research, 14, 355-375. https://doi.org/10.1177/1362168810375362

Storch, N., \& Wigglesworth, J. (2003). Is there a role for the use of the L1 in an L2 setting? TESOL Quarterly, 374), 760-770. https://doi.org/10.2307/3588224

Swain, M., \& Lapkin, S. (2000). Task-based second language learning: The uses of the first language. Language Teaching Research, 4(3), 251-274. https://doi.org/10.1191/136216800125087

Tarone, E. (1977). Conscious communication strategies in interlanguage: A progress report. In H.D. Brown, C.A. Yorio, \& R.C. Crymes (Eds.), On TESOL 77: Teaching and learning English as a second language: Trends in research and practice (pp. 194-203). Washington, DC: TESOL.

Tarone, E. (1983). Some thoughts on the notion of communication strategy. In C. Faerch \& G. Kasper (Eds.), Strategies in interlanguage communication (pp. 61-74). New York: Longman Ink.

Tarone, E., \& Yule, G. (1987). Communication strategies in East-West interactions. In L.E. Smith (Ed.), Discourse across cultures: Strategies in world Englishes (pp. 49-65). New York: Prentice Hall.

Viladot, J., \& Celaya, M. (2007). 'How do you say preparar?': L1 use in EFL oral production and task-related differences. In M. Losada Friend et al. (Eds.), Proceedings of the 30th international AEDEAN conference. Huelva: U de Huelva. 
Vraciu, A., \& Pladevall-Ballester, E. (2020). L1 use in peer interaction: exploring time and proficiency pairing effects in primary school EFL. International Journal of Bilingual Education and Bilingualism. https://doi.org/10.1080/13670050.2020.1767029

Wang, L.M. (2008). EFL 学习者习得交际策略的性别差异研究 [A study of gender differences in communication strategies by EFL learners]. Foreign Languages and Their Teaching, 8, 37-41.

Dr. María Martínez-Adrián is an Associate Professor at the UPV/EHU and a member of the Laslab research group (www.laslab.org). She has co-edited the volumes Contemporary Approaches to Second Language Acquisition published by John Benjamins (Spanish Association of Applied Linguistics award 2014), Crosslinguistic influence: From empirical evidence to classroom practice published by Springer and a special issue on L1 use in CLIL/CBI settings published by the International Journal of Bilingual Education and Bilingualism. Her work has appeared in books published by Springer and Multilingual Matters, and in journals such as RESLA, IJES, ITL, JICB, LTR, EUJAL, IRAL, INJAL, SSLLT, among others.

First version received: September, 2020 Final version accepted: October, 2020 